\title{
The Company You Keep: How Voters Infer Party Positions on European Integration from Governing Coalition Arrangements
}

\author{
James Adams University of California, Davis \\ Lawrence Ezrow University of Essex \\ Christopher Wlezien University of Texas at Austin
}

\begin{abstract}
Recent studies document that voters infer parties' left-right positions from governing coalition arrangements. We show that citizens extend this coalition-based heuristic to the European integration dimension and, furthermore, that citizens' coalition-based inferences on this issue conflict with alternative measures of party positions derived from election manifestos and expert placements. We also show that citizens' perceptions of party positions on Europe matter, in that they drive substantial partisan sorting in the electorate. Our findings have implications for parties' election strategies and for mass-elite policy linkages.
\end{abstract}

Replication Materials: The data, code, and any additional materials required to replicate all analyses in this article are available on the American Journal of Political Science Dataverse within the Harvard Dataverse Network, at: https://dataverse.harvard.edu/dataset.xhtml?persistentId=doi:10.7910/DVN/8OWJAE.

$\mathrm{T}$ wo recent studies analyze how voters infer parties left-right positions from the composition of the national governing coalition. Fortunato and Stevenson (2013) find that voters perceive coalition partners' left-right positions as more similar than is implied by the policy tone of their election manifestos, and Fortunato and Adams (forthcoming) conclude that citizens project the prime minister's position onto its junior coalition partners, but not vice versa. We extend this research to address the following questions: Do voters apply similar heuristics to parties' positions on European integration, a more focused issue than the left-right dimension and one that is increasingly salient for European politics? Do these heuristics have consequences for voters' policy beliefs and their party support? And, do citizens apply coalitionbased heuristics appropriately-that is, are their inferences about party positions on Europe supported by alternative measures such as experts' party placements and content analyses of parties' election manifestos?
We analyze survey data from eight Western European party systems between 1999 and 2009, reaching three conclusions. First, citizens infer parties' positions on Europe based on a coalition heuristic: Namely, when citizens perceive the prime minister's party shifting toward a more (less) pro-Europe position, these citizens tend to perceive junior coalition partners shifting their policies in the same direction. By contrast, citizens do not perceive opposition parties shifting their policies in tandem with the prime minister's party.

Second, voters' coalition-based heuristics matter, in that they prompt partisan sorting in the electorate, whereby shifts in voter perceptions of party positions on Europe prompt shifts in party supporters' positions.

Third, we show that voters privilege the coalition heuristic over more nuanced information, in that their perceptions that coalition partners shift their positions in the same direction over time are not supported by content analyses of parties' Euromanifestos or by experts'

James Adams is Professor, Department of Political Science, 670 Ker Hall, University of California, Davis, Davis, CA 95616 (jfadams@ucdavis.edu). Lawrence Ezrow is Professor, Department of Government, University of Essex, Wivenhoe Park, Colchester C04 3SQ United Kingdom (ezrow@essec.ac.uk). Christopher Wlezien is Hogg Professor of Government, Department of Political Science, University of Texas at Austin, 158 W. 21st Street, Austin, TX 78712-1704 (wlezien@austin.utexas.edu).

A previous version of this article was presented at the annual meeting of the Midwest Political Science Association, Chicago, in April 2014. We thank Zach Greene, Bonnie Meguid, and seminar participants at the University of Maryland at College Park and UC Merced for valuable comments. We also thank Tobias Bohmelt, Daina Chiba, and Ron Lehrer for assistance on this article.

American Journal of Political Science, Vol. 00, No. 0, xxx 2015, Pp. 1-13 
judgments. Given that experts plausibly weigh information besides the composition of the governmentincluding parliamentary debates, politicians' speeches and interviews, party press releases, and government policy outputs-this suggests that voters emphasize the simple coalition heuristic while discounting the more varied information sources that experts consider.

Our conclusions have several interesting implications. First, our findings on the coalition-based heuristic voters apply to European integration parallel the Fortunato-Stevenson (2013) findings for left-right policies, which suggest that this may be a general heuristic that voters apply across diverse issue domains. This pattern is striking, given that the theoretical rationale for inferring parties' positions on Europe from governing coalitions (which we review below) is weaker than the rationale for applying this heuristic to left-right politics. This suggests that citizens apply this heuristic across a wide range of policies.

Second, we find it striking that citizens' coalitionbased inferences about parties' positions on Europe are not supported by expert judgments or by content analyses of party manifestos, especially given the growing salience of Europe as displayed in the bitter public debates over the financial assistance packages offered to distressed economies in Greece, Spain, Ireland, and Portugal, and the growth of populist, anti-European integration parties such as Golden Dawn in Greece, the French National Front, Italy's Five Star movement, and the Dutch Party for Freedom. While we are reluctant to ascribe "mistakes" to rank-and-file voters simply because their perceptions of party positions clash with experts' views (and with party manifestos), our study provides some evidence that citizens should be cautious about applying the coalition-based heuristic to European integration, although, as discussed below, it may serve voters well for inferring parties left-right positions. Our article thereby contributes to the literature analyzing potential problems that may arise when citizens use information shortcuts (e.g., Boudreau and MacKenzie 2014; Dancey and Sheagley 2013; Lau and Redlawsk 2001).

Third, our findings suggest that junior partners in governing coalitions should project that citizens will project the position of the prime minister's party onto its junior partners. This implies that a party such as the British Liberal Democrats, whose identity is tied in part to its positive stance toward Europe, could anticipate that governing with the more anti-European prime ministerial party (the Conservatives) would weaken its own pro-Europe image-a dynamic that may alienate the Liberal Democrats' pro-European core supporters.

\section{Will Citizens Use Coalition-Based Heuristics to Infer Party Positions on Europe? Theoretical Arguments}

Theoretical and empirical studies explore how electoral systems condition parties' incentives to moderate their policies (e.g., Calvo and Hellwig 2011), and whether parties respond to their core supporters' beliefs (e.g., Dalton 1985). These analyses implicitly assume that voters accurately perceive parties' policies, yet while survey respondents' party placements correlate with the codings of parties' manifestos and also with experts' placements (Bakker, Jolly, and Polk 2012; Dalton, Farrell, and McAllister 2011), studies find that over time, citizen perceptions of party policy shifts only weakly track these alternative measures (Adams, Ezrow, and Somer-Topcu 2011; Fernandez-Vasquez 2014). ${ }^{1}$ These findings raise the following question: How and why do voters' perceptions change? Fortunato and Stevenson (2013) argue that voters infer that governing parties' positions converge on leftright policies because voters recognize that coalition partners experience pressure to compromise over policy (e.g., Ganghof and Brauninger 2006), and that parties with similar positions often coalesce (Martin and Stevenson 2010). Fortunato and Stevenson (2013) demonstrate that citizens perceive coalition partners' positions as more similar than is implied by the left-right tone of their policy manifestos, whereas Fortunato and Adams (forthcoming) find that citizens project the prime ministerial party's left-right position onto its junior partner(s), but not vice versa.

Here we ask: Should we expect the above findings on citizens' perceptions of parties' left-right positions to extend to more focused policy issues such as European integration? This question is interesting because the rationale for applying the coalition heuristic to issues that do not map onto left-right politics appears weak. The argument that citizens will apply coalition-based heuristics across diverse policy domains is that the considerations outlined above may extend beyond left-right issues: Namely, coalition negotiations plausibly encompass all relevant policies, and moreover, the norm of collective cabinet responsibility applies to all government policies. By contrast, several considerations cast doubt on whether citizens will (or should) apply coalition heuristics to other issues. First, in most European party systems, post-election coalition negotiations revolve primarily around issues such as taxes and social welfare policies that

${ }^{1}$ Note that there is evidence that members of the public notice changes in government policy outputs and respond thermostatically in various countries and policy domains (e.g., Soroka and Wlezien 2010; Wlezien and Soroka 2012). 
map onto left-right economic policies (Muller and Strom 2000). Citizens who recognize this pattern may hesitate to infer governing parties' positions on issues that cross-cut left-right politics. Second, public opinion research concludes that left-right issues are often most salient to the public (Powell 2000; Soroka and Wlezien 2010), so that citizens may perceive parties' overall left-right positions more accurately than the parties' positions on more specific dimensions. Given that citizens must perceive (at least) one governing party's position in order to apply the coalition heuristic, citizens' ignorance of party positions on less salient dimensions hampers their abilities to apply coalition heuristics to such issues.

We evaluate these arguments by analyzing voters' party perceptions on a dimension that does not map neatly onto left-right economic politics, namely, European integration. We analyze this dimension for two reasons. First, although research finds that Europe is less salient to citizens than are left-right issues (see, e.g., Evans 1998), its salience has increased over time (Franklin and Wlezien 1997). This is especially true in polities such as Greece, Ireland, Spain, and Portugal, whose governments encountered widespread public disapproval of the austerity policies they implemented to conform with the terms of international loans; Germany, where the fall 2013 national election campaign featured intense debates over the financial assistance packages to distressed European Union (EU) member states; and Britain, where the Conservative Party has been bitterly divided on Europe for over 20 years, prompting Prime Minister David Cameron to promise a national referendum on European integration, scheduled to take place before the end of 2017.

Second, European integration is interesting because research uncovers inconsistent relationships between parties' left-right positions and their stances toward Europe, so that-even if voters infer parties' left-right positions from coalitions-citizens may struggle to use these estimates to infer parties' stances toward Europe (see, e.g., Bakker, Jolly, and Polk 2012; Bakker et al. 2015; De Vries and Hobolt 2012). ${ }^{2}$ Hence, if citizens apply the coalition heuristic to European integration (a dimension that crosscuts left-right debates and one that plausibly exerts little influence on government formation) they likely apply this heuristic across many different issues. Finally, European integration is the only dimension besides left-right

${ }^{2}$ In particular, Bakker et al. (2015) uncover a curvilinear relationship between parties' left-right positions and their stances toward Europe, with radical left- and right-wing parties typically taking more euroskeptic positions than do moderate, mainstream parties. The authors also identify variations in these relationships between western and eastern European party systems. These complex, contextual variations plausibly depress citizens' abilities to infer parties' positions on Europe from their left-right positions. for which we have extensive cross-nationally comparable measures of citizens' party placements. Specifically, respondents in the European Election Studies-which were administered in Austria, Britain, Denmark, Finland, France, Germany, Greece, Ireland, Italy, the Netherlands, Portugal, and Spain at the time of the European parliamentary elections held in 1999, 2004, and $2009^{3}$-were asked to place themselves and each national party on a scale ranging from 1 (European unification has already gone too far) to 10 (it should be pushed further).

\section{Model Specification}

We specify a regression model to evaluate how citizens' perceptions of party shifts on European integration respond to the composition of governing coalitions. Our dependent variable is the change in the focal party $j$ 's policy image between the year of the current and the previous European parliamentary election, defined as the difference between the party's mean perceived position in the current European Election Study (EES) survey and its mean perceived position in the previous survey, computed over all respondents who provided valid party placements. We label this variable [Party j's perceived shift $(t)]$. Our independent variables are [Party j's perceived position $(t-1)]$, which denotes party $j$ s mean perceived position at the time of the previous European parliamentary election; [PM party's perceived shift $(t)]$, which denotes the perceived shift of the current prime ministerial (PM) party, again based on the EES respondents' party placements; and [party $j$ is in government $(t)$ ], a dummy variable that denotes whether the focal party was in government at the time of the current EES survey. We specified the following model, to be estimated over all parties except for the prime ministerial party:

$$
\begin{aligned}
& \text { Party j's perceived shift }(t) \\
& =b_{1}+b_{2}[\text { Party } j \text { 's perceived position }(t-1)] \\
& +b_{3}[\text { PM party's perceived shift }(t)] \\
& +b_{4}[\text { Party } j \text { is in government }(t)] \\
& +b_{5}[\text { Party } j \text { is in government }(t) \\
& \quad \times \text { PM party's perceived shift }(t)] .
\end{aligned}
$$

${ }^{3}$ In the analyses we report below, we exclude Britain, France, Greece, and Spain because these countries did not feature coalition governments during the period of our study. We also exclude Belgium and Sweden from our study because subjects were not asked for their party placements in 2004, which interrupts time-series data for these countries. 
To evaluate the relationship between the PM party's policy image and other parties' images, the key coefficients are those on the [PM party's perceived shift $(t)]$ variable and the interaction of this variable with the variable [Party $j$ is in government $(t)]$. The coefficient $\mathrm{b}_{3}$ on [PM party's perceived shift $(t)]$ denotes the relationship between changes in the PM party's perceived position and changes in voter perceptions of opposition parties. A negative coefficient would denote that voters tend to perceive opposition parties shifting in the opposite direction to the PM party's perceived shift-an effect that might arise if voters infer that opposition parties oppose the PM party's policies. The coefficient $b_{5}$ on the interaction [Party $j$ is in government $(t) \times P M$ party's perceived shift $(t)]$ denotes how the relationship between the PM party's perceived shift and the perceived shifts of its junior coalition partner(s) differs from that for opposition parties. A positive coefficient on this interaction would denote that, compared to opposition parties, voters perceive the positions of the PM party and its junior partners shifting in parallel on European integration - a relationship that would extend the empirical findings of Fortunato and Stevenson (2013) and Fortunato and Adams (n.d.), who analyze coalition partners' left-right images. ${ }^{4}$

Our specification also includes the party's lagged perceived position, [Party j's perceived position $(t-1)$ ], to control for voters' long-term perceptions of the party's position, and for whether, when party placements are above (below) this "equilibrium," they tend to subsequently shift downward (upward). We have replicated all of our models omitting this variable, and the resulting estimates support the same substantive conclusions that we report below.

Finally, note that we speak in the language of statistical "relationships" between voters' perceptions of different parties' policy shifts, without specifying the underlying causal processes. In particular, when voters perceive junior coalition partners' policy shifts tracking the PM party's shift - the pattern we estimate below-does this occur because citizens project the PM party's policy shift onto its junior coalition partners, or vice versa? Or, alternatively, do citizens update their perceptions of both PM parties and junior partners in response to factors such as the content of party elites' speeches and interviews, election manifestos, and government policy outputs? We address these issues below, but we note here that

${ }^{4}$ We note that our specification analyzes whether voters' perceptions of opposition parties and junior coalition partners are related to their perceptions of the PM party's short-term policy shift. This perspective is necessary given the structure of our data, where we have measures of voters' perceptions of the positions of a large number of parties but over only three time points (the 1999, 2004, and 2009 European Election Studies). our decision to calibrate junior partners' and opposition parties' perceived policy shifts (the dependent variable in our model) against the PM party's perceived shift reflects the theoretical and empirical reasons (outlined above in our summary of the research of Fortunato, Stevenson, and others) to expect citizens to project PM parties' positions onto their junior partners, and not vice versa.

\section{Results}

We estimated the parameters of Equation (1) on the 56 perceived party shifts in our data set in eight European party systems that featured coalition governments during the period of our study: Austria, Denmark, Finland, Germany, Ireland, Italy, the Netherlands, and Portugal. Table 1 reports the set of parties that we analyzed, and Table 2 reports the means and standard deviations of the observed values of the variables in our data set. These values suggest that voters perceived parties undertaking modest policy shifts on European integration during the period of our study: The mean magnitudes of parties' perceived shifts are on the order of 0.5 units on the 1-10 European integration policy scale (see column 2 in Table 2). This perceived party policy stability on Europe parallels findings on the left-right dimension (Dalton and McAllister n.d.), and it may reflect that political parties plausibly maintain stable policies in order to avoid charges of flip-flopping (see, e.g., Budge 1994). Finally, the table reports that voters perceived both governing and opposition parties shifting toward (modestly) more pro-Europe positions, on average; that is, the mean value of the [PM party's perceived shift $(t)]$ variable is positive—and roughly equal-for both types of parties. This latter finding is interesting given research that during the time period under review, governing parties faced pressures to adopt pro-Europe positions as they negotiated for their country's interests in the European Parliament (see, e.g., De Vries and Hobolt 2012; Hooghe, Marks, and Wilson 2002). Our data suggest that, this dynamic notwithstanding, citizens did not perceive governing parties shifting toward pro-Europe positions to a significantly greater extent than opposition parties.

Our data are time-series cross-sectional. Estimating a simple regression on the pooled data can lead to erroneous conclusions due to unobserved heterogeneity between parties, although this problem is mitigated with the differenced model specified in Equation (1) (see, e.g., Wooldridge 2002). We estimate robust standard errors clustered by party (Rogers 1993). ${ }^{5}$

\footnotetext{
${ }^{5}$ We reestimated the model using standard errors clustered by election, and the standard errors for the key coefficients increase only marginally.
} 


\section{TABLE 1 Parties Included in the Empirical Analyses}

\begin{tabular}{ll}
\hline Austria & Ireland \\
FPO Freedom Party & FF Fianna Fail \\
GA The Greens & FG Fine Gael \\
OVP People's Party & Green Party \\
SPO Social Democratic Party & LP Labour Party \\
& \\
Denmark & Italy \\
DF People's Party & AN National Alliance \\
KF Conservatives & Forza Italia \\
People's Party & LN Northern League \\
RV Radical Left Party & RC New Communists \\
SD Social Democratic Party & \\
SF Socialist People's Party & Netherlands \\
V Liberal Party & CDA Christian \\
& Democratic Appeal \\
Finland & D66 Democrats 66 \\
KD Christian & GL Green Left \\
Democratic Party & PvdA Labour Party \\
KESK Centre Party & SP Socialist Party \\
KOK National Coalition Party & VVD People's Party for \\
SFP True Finns & Freedom and Dem. \\
SSDP Social & PSP Socialist Party \\
Democratic Party & Portugal \\
VAS Left Alliance & CDU Portuguese \\
VIHR Green League & Communist Party \\
Germany & Greens \\
CDU-CSU Christian & \\
Democrats & \\
FDP Free Democratic Party & \\
GRUNEN Green Party & \\
PDS/LINKE Party of & \\
\hline
\end{tabular}

We report our parameter estimates in column 1 of Table 3, where the dependent variable, [Party j's perceived shift $(t)]$, is the change in EES respondents' mean placements of the focal party j's position between the years of the current and the previous European Parliament elections. Before turning to effects pertaining to coalitions, note that we find no evidence that being in government directly affects voters' perceptions of party shifts; that is, the estimate on the variable [party $j$ is in government $(t)]$ is small and insignificant. In addition, the coefficient on the variable [Partyj's perceived position $(t-1)]$ is negative and significant while the coefficient on the intercept is positive and significant, which implies a "regression to the mean" in voter placements; that is, when party placements are TABLE 2 Descriptive Statistics: Dependent and
Independent Variables

\begin{tabular}{|c|c|c|c|}
\hline & $\begin{array}{c}\text { Mean } \\
\text { Value } \\
(1)\end{array}$ & $\begin{array}{c}\text { Mean } \\
\text { Absolute } \\
\text { Value } \\
(2)\end{array}$ & $\begin{array}{c}\text { Minimum } \\
\text { and Maximum } \\
\text { Values } \\
(3)\end{array}$ \\
\hline $\begin{array}{l}\text { Party j's perceived } \\
\text { shift }(t)\end{array}$ & $\begin{array}{c}0.14 \\
(0.61)\end{array}$ & $\begin{array}{c}0.52 \\
(0.36)\end{array}$ & $1.35 ; 1.41$ \\
\hline $\begin{array}{l}\text { Party j's perceived } \\
\quad \text { shift }(t)- \\
\text { governing parties }\end{array}$ & $\begin{array}{c}0.22 \\
(0.54)\end{array}$ & $\begin{array}{c}0.47 \\
(0.33)\end{array}$ & $-0.58 ; 1.41$ \\
\hline $\begin{array}{l}\text { Party j's perceived } \\
\text { shift }(t)- \\
\text { opposition } \\
\text { parties }\end{array}$ & $\begin{array}{c}0.10 \\
(0.65)\end{array}$ & $\begin{array}{c}0.54 \\
(0.37)\end{array}$ & $-1.35 ; 1.32$ \\
\hline $\begin{array}{c}\text { Party j's perceived } \\
\text { position }(t-1)\end{array}$ & $\begin{array}{l}5.45 \\
(0.94)\end{array}$ & $\begin{array}{c}5.45 \\
(0.94)\end{array}$ & $3.20 ; 7.56$ \\
\hline $\begin{array}{l}\text { PM party's } \\
\text { perceived shift }(t)\end{array}$ & $\begin{array}{l}-0.10 \\
(0.57)\end{array}$ & $\begin{array}{c}0.47 \\
(0.30)\end{array}$ & $-0.92 ; 0.89$ \\
\hline $\begin{array}{l}\text { Party } j \text { is in } \\
\text { government }(t)\end{array}$ & $\begin{array}{c}0.32 \\
(0.47)\end{array}$ & $\begin{array}{c}0.32 \\
(0.47)\end{array}$ & $0 ; 1$ \\
\hline
\end{tabular}

Note: The numbers in parentheses are the standard deviations of the reported values. All of the variables are calibrated along a 10-point scale for which higher numbers denote a more positive attitude toward European integration. The measures of citizens' perceptions of parties' shifts on European integration are drawn from European Election Study (EES) survey data from Austria, Denmark, Finland, Germany, Ireland, Italy, the Netherlands, and Portugal. The EES surveys were administered in 1999, 2004, and 2009. The variable definitions are given in the text.

unusually large (or small) relative to the historical average placement of the party position, then subsequent placements will tend to revert to values closer to this historical average. This pattern is found in various social and physical settings, and it may reflect measurement issues and/or underlying dynamic processes (see, e.g., Barnett, van der Pouls, and Dobson 2005). The measurement issue is that the party's perceived position variable is bounded by the endpoints 1 and 10 of the EES European integration scale, so that when survey respondents placed a party at a radical position at the previous time period, they could not shift their placement of this party to a significantly more extreme position at the current time period-but they could shift their party placement toward a substantially more moderate position. The dynamic process is that, when a party's lagged position was extreme, this may indicate that the party's most strongly pro-Europe (anti-Europe) faction was in the ascendant at the previous time period, in which case a diminution of this faction's influence at the current time period might moderate the party's position. ${ }^{6}$

${ }^{6}$ Intraparty policy alternation between party factions is consistent with conclusions reported by Budge, Ezrow, and McDonald (2010). 


\section{TABle 3 Analyses of Citizens' Perceptions of Parties' Policy Shifts on European Integration}

\begin{tabular}{|c|c|c|c|}
\hline $\begin{array}{l}\text { Independent } \\
\text { Variables }\end{array}$ & $\begin{array}{c}\text { Basic } \\
\text { Model } \\
(1\end{array}$ & $\begin{array}{c}\text { EMP } \\
\text { Codings } \\
(2)\end{array}$ & $\begin{array}{l}\text { Chapel } \\
\text { Hill } \\
\text { Experts } \\
(3)\end{array}$ \\
\hline $\begin{array}{l}\text { Party j's perceived } \\
\text { position }(t-1)\end{array}$ & $\begin{array}{c}-0.22 \\
(0.11)\end{array}$ & $\begin{array}{c}-0.23^{*} \\
(0.11)\end{array}$ & $\begin{array}{r}-0.20^{*} \\
(0.10)\end{array}$ \\
\hline $\begin{array}{l}\text { PM party's } \\
\quad \text { perceived shift }(t)\end{array}$ & $\begin{array}{l}-0.07 \\
(0.17)\end{array}$ & $\begin{array}{l}-0.08 \\
(0.17)\end{array}$ & $\begin{array}{c}0.05 \\
(0.15)\end{array}$ \\
\hline $\begin{array}{l}\text { Party } j \text { is in } \\
\quad \text { government }(t)\end{array}$ & $\begin{array}{c}0.11 \\
(0.14)\end{array}$ & $\begin{array}{c}0.11 \\
(0.14)\end{array}$ & $\begin{array}{c}0.15 \\
(0.14)\end{array}$ \\
\hline $\begin{array}{l}\text { PM party's } \\
\text { perceived shift }(t) \\
\times \text { Party is in } \\
\text { government }(t)\end{array}$ & $\begin{array}{l}0.73^{* *} \\
(0.21)\end{array}$ & $\begin{array}{l}0.75^{* *} \\
(0.21)\end{array}$ & $\begin{array}{l}0.67^{* *} \\
(0.20)\end{array}$ \\
\hline $\begin{array}{c}\text { Party j's shift }(t)- \\
\text { EMP codings }\end{array}$ & & $\begin{array}{c}-0.24 \\
(0.23)\end{array}$ & \\
\hline $\begin{array}{l}\text { Party j's shift }(t)- \\
\text { Chapel Hill } \\
\text { experts }\end{array}$ & & & $\begin{array}{c}0.26 \\
(0.14)\end{array}$ \\
\hline Intercept & $\begin{array}{l}1.27^{*} \\
(0.60)\end{array}$ & $\begin{array}{l}1.31^{*} \\
(0.60)\end{array}$ & $\begin{array}{l}1.16^{*} \\
(0.55)\end{array}$ \\
\hline $\mathrm{R}^{2}$ & 0.21 & 0.23 & \\
\hline
\end{tabular}

Note: $\mathrm{N}=56$. Standard errors (clustered by party) are in parentheses. For these analyses, the dependent variable was the change in the focal party's perceived position on European integration at the time of the current European parliamentary election compared to the previous election, as perceived by all European Election Study (EES) respondents who provided valid party placements. The data are from EES surveys administered in Austria, Denmark, Finland, Germany, Ireland, Italy, the Netherlands, and Portugal, near the times of the elections to the European Parliament held in 1999, 2004, and 2009. For these analyses, the parties' positions as perceived by the survey respondents were all calibrated along a $1-10$ scale where higher numbers denote more pro-Europe positions. The independent variables are defined in the text.

$* * \mathrm{p} \leq .01, * \mathrm{p} \leq .05$, two-tailed tests.

Below, we discuss robustness checks in which we reestimated our models while omitting the lagged perceived party position variable, which support substantive conclusions that are identical to those we also discuss below.

We now consider the coalition-based effects that interest us. If citizens' perceptions of the PM party's policy shift are related to opposition parties' perceived shifts, we would expect a significant coefficient on the variable [PM party's perceived shift $(t)]$. However, the estimate is near zero and statistically insignificant. By contrast, citizens' perceptions of junior coalition partners' shifts are strongly related to the PM party's perceived shift: The coefficient on the interacted variable [party $j$ is in government $(t) \times P M$ party's perceived shift $(t)],+0.73$, is statistically significant $(\mathrm{p}<.01)$ and denotes that, compared to opposition parties, citizens shift their perceptions of junior partners' positions in tandem with the PM party's perceived shift. The conditional effect, +0.66 (s.e. $=0.11, \mathrm{p}<.001)$, is the sum of the parameter estimates on the $[P M$ party's perceived shift $(t)]$ variable and the [party $j$ is in government $(t) \times P M$ party's perceived shift $(t)]$ variable, and it implies that a one-unit perceived shift toward a more (less) pro-Europe position by the PM party is associated with a 0.66 -unit shift in citizens' perceptions of junior coalition partners in the same direction, where all parties' positions are calibrated along a 1-10 scale. This estimate implies that the difference between a perceived PM party shift of -0.32 units on the European integration scale (one standard deviation below the mean value for governing parties in our data set) and a perceived PM party shift of +0.76 units (one standard deviation above the mean) is associated with an increase of 0.71 units in the junior partner's perceived shift. Given that the values of the governing parties' perceived shifts in our data range from -0.58 units to +1.41 units (see column 3 in Table 2), this difference of 0.71 units is more than one-third of the entire range of values in our data.

Figure 1 depicts the effects of perceived PM party shifts on junior coalition partners' and opposition parties' perceived shifts. The former are displayed as a dotted line and the latter as a solid line (with shaded confidence intervals). ${ }^{7}$ The figure illustrates that perceived PM shifts exert no effect on citizens' perceptions of opposition parties but a strongly positive effect on perceptions of coalition partners. These patterns suggest that voters employ a coalition-based heuristic to update their perceptions of party policy positions on European integration.

\section{Do Voters Apply the Coalition-Based Heuristic Appropriately? Comparing Voters' Perceptions of Party Shifts with Experts' Perceptions and Party Manifestos}

Our computations imply that citizens perceive the positions of prime ministerial parties and junior coalition partners-but not opposition parties—shifting in the same direction over time on European integration. While

\footnotetext{
${ }^{7}$ These estimates are calculated while holding the [Partyj's perceived position $(t-1)$ ] variable at its mean value. The confidence intervals are calculated so as to allow us to reflect statistical significance at the .05 level.
} 
Figure 1 Predicted Effects of Perceived PM Party Shifts on Perceived Shifts by Coalition Partners and Opposition Parties.

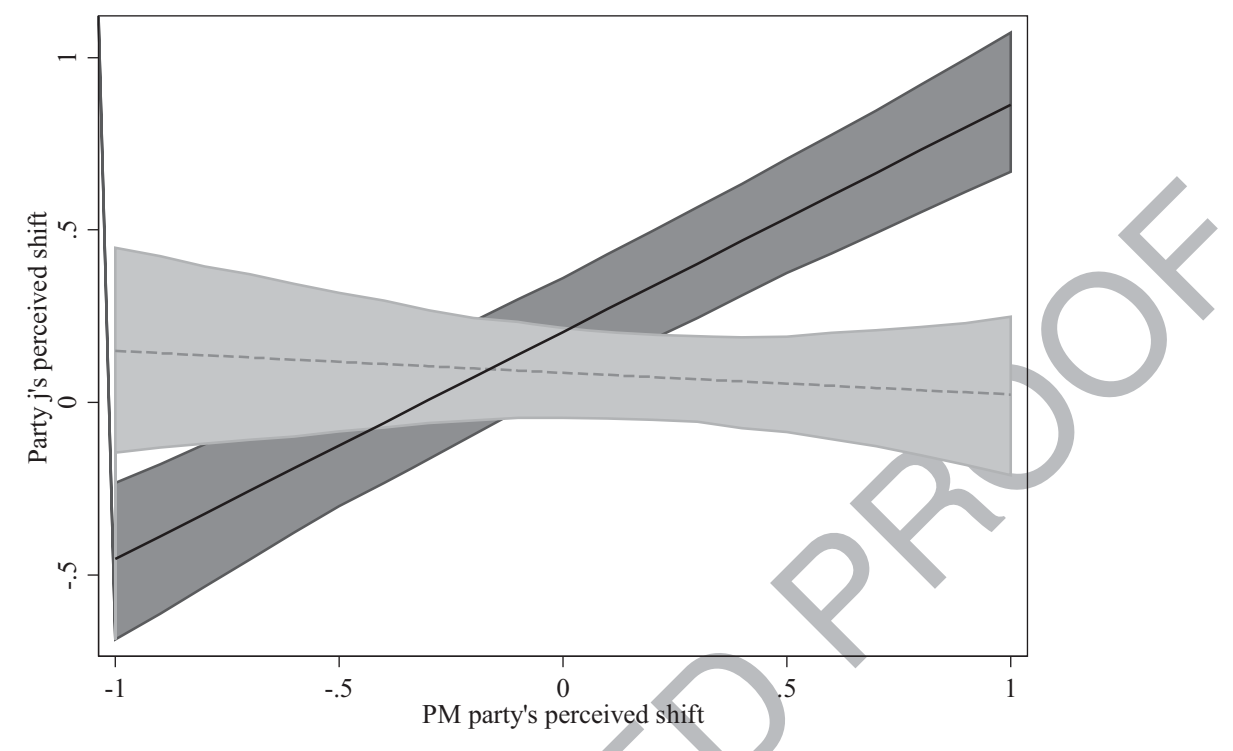

Note: The figure charts the predicted effects of the [PM party's perceived shift $(t)$ ] variable on the [Party j's perceived shift $(t)$ ] variable, for opposition parties (dotted line) and junior coalition parties (solid line), computed for the coefficient estimates reported in Table 3 (Model 1). The shaded regions are set so that the probability is under .05 that the predicted values overlap. For these analyses, the [Party j's perceived position $(t-1)$ ] variable is set at its mean value.

these patterns suggest that citizens apply coalition heuristics, an alternative explanation is that citizens weigh other factors, such as parties' election manifestos, party elites' speeches and interviews, and government policy outputs. Suppose, for instance, that junior coalition partners update their policy statements to support the prime minister's policies, and that citizens respond to these statements rather than to the fact of the coalition itself. In this case, failure to control for party elites' policy statements may prompt the spurious conclusion that citizens employ a coalition-based heuristic.

To address this possibility, we analyzed the policy tones of the Euromanifestos that the parties in our data set published in the run-ups to the European parliamentary elections of 1999, 2004, and 2009. Specifically, we analyzed the codings of party positions on European integration derived from the European Manifesto Project (EMP) analyses of parties' Euromanifestos ${ }^{8}$ to assess whether these EMP codings display significantly positive

${ }^{8}$ The EMP coders counted the percentages in each Euromanifesto dedicated to 14 pro-EU and 15 anti-EU issues, and then subtracted the percentage of anti-EU mentions from the percentage correlations between the stated policy shifts of PM parties and those of their junior coalition partners.

In fact, the EMP codings display little tendency for PM parties and their junior coalition partners to shift their positions in the same direction over time. The correlation between the EMP-based codings of PM parties' shifts on European integration and junior partners' shifts is weak and insignificant $(\mathrm{r}=.18, \mathrm{p}=.44)$. This implies that citizens' strong tendencies to perceive coalition partners shifting their positions in the same direction $(r=.65$, $\mathrm{p}=.004)$ is not due to citizens' responses to party manifestos. Moreover, given findings that party elites coordinate their overall election campaign messages with the policy tone of their manifestos (Adams, Ezrow, and Somer-Topcu 2011), this suggests that voters' perceptions that coalition partners shift their positions in tandem is not a response to the overall policy message parties convey during election campaigns.

of pro-EU mentions. Details on the methodology for coding Euromanifestos can be found on the project website: http://www.eeshomepage.net/seiten/euromanifestos.html. 
The proposition that voters discount campaigns for the European Parliament will not surprise scholars who classify these contests as "second-order" elections that arouse little public interest (see, e.g., De Vreese et al. 2006). To address the possibility that citizens respond to information beyond that conveyed during these election campaigns, we analyzed political experts' perceptions of parties' policy shifts on Europe. Experts plausibly weigh all relevant information when estimating party positions, including party elites' speeches and interviews, party press releases, parliamentary debates, election manifestos, and government policy outputs. Hence, if experts perceive coalition partners' policies shifting in the same direction over time, this may indicate that ordinary citizens perceive this pattern because they respond to diverse information sources, as opposed to relying on the coalition heuristic.

Our measure of experts' perceptions is derived from the Chapel Hill expert surveys (see Bakker et al. 2015), in which experts placed each party in their party system on a scale running from 1 (strongly opposed towards European integration) to 7 (strongly in favor of European integration). We rely on the 1999, 2002, 2006, and 2010 Chapel Hill surveys, using linear interpolations to calibrate the experts' mean party placements against voter placements derived from the 1999, 2004, and 2009 EES surveys. The correlation between experts' perceptions of PM parties' and junior partners' shifts on Europe is weak and insignificant $(\mathrm{r}=.28, \mathrm{p}=.27)$, which suggests that (1) rank-and-file voters rely more strongly on the coalition heuristic than do experts and (2) voters' perceptions that coalition partners' positions shift together are not due to the non-coalition-related information that experts plausibly prioritize.

Multivariate Analyses That Incorporate Manifesto Codings and Expert Perceptions. To further substantiate our conclusions, we reestimated the parameters of models identical to Equation (1) above except that we controlled for shifts in the policy tone of the parties' Euromanifestos, and for experts' perceptions of party shifts. For these analyses, we recalibrated the EMP codings of party manifestos, along with experts' party placements, from the original scales (ranging from -100 to +100 in the EMP codings and from 1 to 7 in the Chapel Hill surveys) to a 1-10 scale, which matches the scale from the European Election Study surveys. ${ }^{9}$

${ }^{9}$ Specifically, we set each expert respondent $i$ 's placement $x_{i j}$ of party $j$ on the $1-7$ scale to the value $\left[1.5\left(x_{i j}\right)-0.5\right]$, which recalibrates these placements to a 1-10 scale. Similarly, we set each EMP coding $x_{j}$ of party $j$ on the -100 to +100 EMP scale to the value $\left[0.045\left(x_{j}\right)\right.$ $+5.5]$, which again recalibrates these codings to a $1-10$ scale.
Column 2 in Table 3 reports parameter estimates for a Euromanifesto Project (EMP) codings model that includes the variable [Party j's shift $(t)-$ EMP codings], which denotes the change in the party's stated position in the current European parliamentary election compared to the previous election, based on the EMP codings. The coefficient estimate on this variable is small and insignificant, which implies that citizens do not respond to party Euromanifestos. ${ }^{10}$ Moreover, the estimates on the variables [PM party's perceived shift $(t)]$ and [party $j$ is in government $(t) \times$ PM party's perceived shift $(t)]$ continue to support our conclusion that citizens' perceptions of junior partners' policy shifts-but not of opposition parties' shifts—-track the PM party's perceived shift: Specifically, a one-unit shift in the PM party's perceived position is associated with a 0.62 -unit shift in the same direction in citizens' perceptions of junior partners.

Column 3 in Table 3 reports parameter estimates for an expert placements model that is identical to Equation (1) above except that we included an additional variable, [Party j's shift $(t)-$ Chapel Hill experts], that denotes the change in the experts' mean placement of party $j$ in the year of the current European parliamentary election compared to the previous election. We estimate a positive coefficient on this variable, indicating that citizens' perceptions of party shifts track experts' perceptions. ${ }^{11}$ In addition, the estimates on the variables [PM party's perceived shift $(t)]$ and [party $j$ is in government $(t) \times$ $P M$ party's perceived shift $(t)$ ] continue to imply that citizens update their perceptions of junior partners and the PM party in tandem-specifically, that a one-unit shift in the PM party's perceived position is associated with a 0.72 -unit shift in the same direction in citizens' perceptions of junior coalition partners. ${ }^{12}$ It is striking that we estimate such large effects when controlling for experts' perceptions, for this implies that rank-and-file voters rely on the coalition-based heuristic more heavily than do political experts. To see this, note that if experts and rank-and-file voters weighed coalition arrangements equally, then our expert perceptions measure, the variable [Party j's shift $(t)$ - Chapel Hill experts], should capture

\footnotetext{
${ }^{10}$ The bivariate correlation between the EMP codings of party policy shifts and our EES-based measure of voters' perceived party shifts is also weak and insignificant $(\mathrm{r}=-.05, \mathrm{p}=.63)$.

${ }^{11}$ The bivariate correlation between the experts' perceptions of party policy shifts and rank-and-file voters' perceptions of these shifts is statistically significant $(\mathrm{r}=.25, \mathrm{p}=.014)$, which is consistent with the results reported in Adams, Ezrow, and Somer-Topcu (2014).

${ }^{12}$ That is, the sum of the coefficients on the [PM party's perceived shift $(t)]$ variable, +0.05 , and the [party $j$ is in government $(t) \times P M$ party's perceived shift $(t)]$ variable, +0.67 , is +0.72 .
} 
the full extent to which ordinary citizens update their perceptions of party positions via the coalition heuristic, in which case the coefficient estimate on the variable [party $j$ is in government $(t) \times P M$ party's perceived shift $(t)]$ would be near zero when we control for experts' perceptions. However, our estimate for this variable remains large and significant. This finding supports Fortunato and Stevenson's (2013) argument that sophisticated citizens have less need to employ the simple coalition heuristic than do unsophisticated citizens. Given that the political scientists and journalists who participated in the Chapel Hill Expert Study surveys are super-sophisticated citizens, they plausibly have little need to rely on the coalition heuristic to infer parties' positions.

Robustness Checks. We performed several analyses to assess the robustness of our findings. First, we reestimated our models from Table 3 while omitting the party's lagged perceived position, [Party j's perceived position $(t-1)$ ], which is intended to capture any regression to the mean in party placements. Second, to assess whether voters' reliance on the coalition heuristic was mediated by economic conditions, we reestimated our models on subsets of cases corresponding to higher (lower) national levels of unemployment, inflation, and GDP growth. Third, to evaluate the effects of possible sampling error on our measures of perceived party shifts, we reestimated our models using errors-in-variable specifications. Fourth, we reestimated our models of parties' perceived policy shifts using their supporters' perceptions of these shifts, as opposed to the entire electorate's perceptions. These analyses, which we report in supplementary materials posted on our website, continue to support our substantive conclusions.

In toto, our results consistently imply that citizens perceive the positions of the prime minister's party and its junior coalition partners-but not opposition parties-shifting together on European integration. This conclusion persists when we control for parties' Euromanifestos, for experts' perceptions of party shifts, for economic conditions, and for possible survey sampling error. Our findings on the coalition heuristic that citizens apply to European integration mirror those that Fortunato and Stevenson (2013) report on left-right policies, which suggest that this represents a general heuristic that citizens apply across diverse policy domains.

Some Reflections on Causal Processes and the Usefulness of the Coalition Heuristic. While our analyses suggest that citizens infer party positions on Europe from coalition arrangements, we have not analyzed whether the public projects the PM party's position onto its junior partners or vice versa, nor whether the coalition heuristic enhances voters' perceptual accuracy. With respect to the first issue, we cannot parse out the reciprocal effects of PM parties' and junior coalition partners' positions because these causal processes produce observationally equivalent patterns whereby coalition partners' policy images shift in tandem. We hope to eventually gain purchase on this issue by incorporating data from the 2014 European Election Study surveys into our analyses, so that we can analyze a longer data series and better estimate the reciprocal long-term effects of PM parties' policy images and those of their junior partners. We note, however, the strong reasons to expect voters to project the PM party's policy shift onto its junior partners, rather than vice versa. In particular, Fortunato and Adams (n.d.) empirically support this pattern with respect to left-right policies, and the authors substantiate this finding by noting that survey-based and experimental research concludes that voters project that the PM party will dominate government policy (see, e.g., Duch, Przepiorka, and Stevenson 2013), and that the norm of collective responsibility prevents junior partners from differentiating their policies from those passed by the government. This view that the PM party - typically the largest party in the coalitiondrives government policy outputs is reflected in empirical studies on political representation, which typically estimate the government's position as the mean position of the governing parties weighted by their sizes (e.g., Powell 2000; Warwick 2001).

Hence, there is a strong case that citizens use the PM party's position on Europe to infer the positions of its junior partners. In addition, given the heavy media coverage of the prime minister's speeches and policy statements, compared to stated positions by other cabinet members, it is plausible that voters infer the PM party's positions from these statements and use them as a baseline to infer junior coalition partners' positions.

The question of whether citizens correctly apply the coalition heuristic to European integration is complex because the answer depends on the validity of the alternative measures of party positions we have analyzed, namely, Euromanifesto codings and experts' judgments-a topic that has prompted widespread debate (see, e.g., Bakker, Jolly, and Polk 2012; Benoit, Mikhaylov, and Laver 2009). While we must proceed cautiously here, we note that neither of these alternative measures supports citizens' perceptions that PM parties and their junior partners shift their policies in tandem. Furthermore, as discussed above, the theoretical rationale for applying the coalition heuristic appears weaker for European integration than for left-right politics.

At the same time, two alternative considerations cast the coalition heuristic in a more positive light. First, in the 
absence of more specific information, voters' application of this heuristic may enhance their inferences about party positions across most issue areas, even if it does not in the (unusual) case of European integration. In this regard, recent research by Cahill and Adams (2014) concludes that coalition partners do in fact converge on issues pertaining to both economic policy and libertarian-authoritarian issues. This suggests that voters' application of the coalition heuristic is a sensible approach to inferring party positions across many issue areas, even if it is less useful with respect to European integration than with respect to other issues. Second, we are reluctant to ascribe "mistakes" to rank-and-file voters when their perceived party positions clash with experts' perceptions, not only because this judgment presupposes that expert judgments are errorfree, but also because this issue raises the following question: How does one conceptualize a party's issue position? In particular, given that the norm of collective cabinet responsibility may be interpreted - at the extreme-as implying that all coalition partners share identical positions, namely, the positions embodied in the government's actual policy outputs, one can make a case that the coalition heuristic is "correct" by definition. While most scholars would see this judgment as overly simplistic, there is room for reasonable disagreement over how much coalition partners' issue positions are defined by their concrete actions (namely, their decision to join the government and to endorse its policies) versus the statements coalition partners issue in their policy manifestos, speeches, press releases, and so on. Our analyses suggest that in weighing the import of words versus actions, rank-and-file voters privilege coalition partners' actions - in particular, their decision to participate in the coalition cabinet- to a greater extent than do political experts, who appear attuned to more varied sources of information.

\section{Do Citizens Update Their Party Support and/or Their Policy Views in Response to Parties' Perceived Shifts? Analyses of Partisan Sorting}

Our finding that citizens apply the coalition heuristic to European integration arguably only matters if citizens also react to parties' perceived shifts by updating their own policy views and/or their party support (i.e., that we observe partisan sorting in response to voters' perceptions). Previous studies find that citizens take policy cues from parties on European integration (Gabel 1998; Ray 2003b; Steenbergen, Edwards, and De Vries 2007) and also at times choose parties based on this issue (Ray 2003a), so that we expect to observe partisan sorting in response to voters' shifting perceptions of party positions.
In analyses of individual-level panel data, we might parse out whether citizens update their party support as opposed to their policy views. However, because we analyze aggregate time-series cross-sectional data, we instead estimate the extent to which either process occurs. Our logic is simple: If parties' perceived policy shifts prompt citizens to update their party support and/or their policy views, we should observe the positions of a party's supporters shifting in the same direction as the party's perceived shift (see, e.g., Erikson, MacKuen, and Stimson 2002). ${ }^{13}$

We specify a multivariate regression model to analyze mass-level partisan sorting on European integration. Our measure of the position of each party's partisan constituency at the time of the current European parliamentary election is the mean self-placement of all European Election Study respondents in that election who supported the focal party. (The appendix presents the party identification question from the EES surveys.) Our dependent variable, [Party $j$ supporters' shift $(t)$ ], is the change in the mean position of party j's supporters between the current European parliamentary election and the previous election. Our independent variables are identical to those in Equation (1) above, except that we include the lagged level of our new dependent variable, [Party $j$ supporters' position $(t-1)]$, and also [Party $j$ 's perceived shift $(t)]$. This latter variable controls for partisan shifting in response to voters' perceptions of the focal party's policy shift: ${ }^{14}$

$$
\begin{aligned}
& \text { Party j supporters' shift }(t) \\
& =b_{1}+b_{2}[\text { Party } j \text { supporters' position }(t-1)] \\
& +b_{3}[\text { Party } j \text { 's perceived shift }(t)] \\
& +b_{4}[\text { PM party's perceived shift }(t)] \\
& +b_{5}[\text { Party } j \text { is in government }(t)] \\
& +b_{6}[\text { Party } j \text { is in government }(t) \\
& \\
& \times \text { PM party's perceived shift }(t)] .
\end{aligned}
$$

Table 4 reports parameter estimates for this partisan sorting specification. The coefficient on the variable [Partyj's

\footnotetext{
${ }^{13}$ That is, such a pattern conforms with a partisan switching process whereby a party's perceived shift toward a more pro-Europe position (for instance) attracts new supporters who hold pro-Europe views while prompting euroskeptics to exit the party, and also to policy cueing whereby the party's perceived shift prompts its preexisting supporters to become more pro-Europe.

${ }^{14}$ As we discuss below, we include the variable [PM party's perceived shift $(t)]$ in our specification to control for the possibility that the supporters of junior coalition partners find the PM party more persuasive due to its alliance with the junior partner, and thereby
} 


\section{TABLE 4 Analyses of Partisan Sorting on European Integration}

\begin{tabular}{lc}
\hline & All Parties (1) \\
\hline Party j's supporters' position $(t-1)$ & $-0.45^{* *}$ \\
& $(0.13)$ \\
Party j's perceived shift $(t)$ & $0.64^{* *}$ \\
& $(0.19)$ \\
PM party's perceived shift $(t)$ & -0.38 \\
& $(0.25)$ \\
Party jis in government $(t)$ & 0.02 \\
& $(0.20)$ \\
PM party's perceived shift $(t) \times$ Party $j$ is & 0.20 \\
in government $(t)$ & $(0.30)$ \\
Intercept & $2.33^{* *}$ \\
& $(0.77)$ \\
$\mathrm{N}$ & 56 \\
$\mathrm{R}^{2}$ & 0.43 \\
\hline
\end{tabular}

Note: Standard errors (clustered by party) are in parentheses. For these analyses, the dependent variable was the change in the mean position of the focal party's supporters on European integration at the time of the current EU election compared to the previous EU election, based on European Election Study respondents' selfplacements in Austria, Denmark, Finland, Germany, Ireland, Italy, the Netherlands, and Portugal. Party supporters were defined as those respondents who considered themselves close to a particular party (the text of the party support question is given in the appendix). The independent variables are defined in the text. $* * \mathrm{p} \leq .01,{ }^{*} \mathrm{p} \leq .05$, two-tailed tests.

perceived shift $(t)],+0.64$, is statistically significant $(\mathrm{p}<$ .01 ) and denotes that when voters perceive a party shifting one unit on the EU scale, the mean position of the party's supporters shifts 0.64 units in the same direction (on average), with parties' and supporters' shifts calibrated along identical 1-10 scales. These estimates imply that the coalition heuristic matters, in that citizens' party perceptions prompt mass-level partisan sorting.

By contrast, the insignificant coefficients on most of the remaining variables provide no evidence that coalition-based considerations prompt additional partisan sorting beyond what is due to parties' perceived policy shifts. ${ }^{15}$ For instance, if junior coalition partners' supporters were especially willing to take policy cues from the prime minister, we should estimate a positive coefficient on the interacted variable [party $j$ is in government $(t) \times P M$ party's perceived shift $(t)]$, which would denote

update their own policy views in the direction of the PM party's position.

${ }^{15}$ We note that the coefficient on the variable [Party j supporters' position $(t-1)]$ is negative and significant, whereas the coefficient on the intercept is positive and significant, which implies a regression to the mean in party supporters' self-placements. that junior partners' supporters shift in the same direction as the PM party's perceived shift (ceteris paribus). However, the estimate on this variable is near zero and insignificant. We conclude that coalition heuristics prompt partisan sorting via their direct effect on citizens' perceptions of party positions, as opposed to junior partners' supporters taking policy cues from the PM party.

\section{Conclusion and Discussion}

Fortunato and Stevenson's (2013) insight, that citizens infer parties' left-right positions from governing coalition arrangements, has important implications for masselite linkages. This finding illuminates how citizens use the simple, sensible coalition heuristic to infer parties' left-right positions, which alleviates citizens' need to obtain more complex information pertaining to party manifestos and press releases, parliamentary debates, and government policy outputs. We find that citizens apply coalition-based heuristics to the increasingly salient issue of European integration. Moreover, we show that the coalition-based inferences citizens make about parties' stances toward Europe matter, in that they prompt masslevel partisan sorting on this issue.

We also identify an important difference between citizens' application of the coalition heuristic to European integration, compared to left-right politics: Namely, while research documents that governments form (and endure) largely based on parties' shared left-right policies, there is no comparable evidence that coalitions revolve around parties' views on Europe, and we demonstrate that the coalition heuristic we identify-namely, voters' inferences that coalition partners' positions on Europe shift in tandem-is not supported by the content of parties' Euromanifestos or by experts' party placements. This suggests that when estimating party positions on European integration, rank-and-file voters diverge from political experts in that voters assign primacy to coalition partners' concrete actions-in particular, the easily observable fact of the governing coalition itself-whereas political experts weigh more varied sources of information, such as parliamentary debates, party elites' speeches and interviews, and parties' election manifestos.

Our study raises several additional issues for future research. First, given the increased salience of European integration over the past five years, parties' coalition negotiations during this period may pertain to European issues more than was the case during the 1999-2009 time frame of our study. We plan to eventually revisit our analyses and incorporate the data from the 2014 European 
Election Study surveys, along with parties' 2014 Euromanifestos and the 2014 wave of the Chapel Hill expert surveys in order to evaluate whether citizens' reliance on the coalition heuristic has increased since 2009.

Another path is to analyze how coalitions influence citizens' perceptions along additional dimensions such as the environment, crime, and immigration. While the lack of cross-nationally comparable surveys poses obstacles to this study, our findings of a coalition heuristic on European integration-in combination with the FortunatoStevenson (2013) findings on left-right issues—suggest that this heuristic may be a general one that citizens apply to various domains.

An additional extension is to explore the dynamics of coalition-based effects under minority governing arrangements. For example, in 2010, the Dutch minority coalition, composed of the People's Party for Freedom and Democracy (VVD) and the Christian Democratic Appeal (CDA), governed with the aid of the far-right, anti-EU Party for Freedom (PVV), which supported the government from outside the formal coalition. We plan to evaluate whether voters apply the coalition heuristic to such government support parties that remain officially outside the cabinet. This issue is relevant to the strategic calculations of radical right parties throughout Europe whose electoral appeal is tied to their anti-EU stances, including the National Front in France, Golden Dawn in Greece, the British National Party, and the Dutch PVV. To the extent that these parties' images as staunch anti-EU parties are compromised when they provide informal support to more moderate governing parties, these radical right parties may have electoral incentives to withhold support from the government.

In this article, we have extended the study of coalition heuristics to European integration policy. We have shown that citizens apply the heuristic to this policy domain and that the inferences citizens draw about party policy shifts prompt partisan sorting in the electorate. We do see various promising extensions, discussed above, which form the subject of future research.

\section{Appendix European Election Surveys}

European integration position of respondents/ parties:

"Some say European unification should be pushed further. Others say it already has gone too far. What is your opinion? Please indicate your views using a 10-point scale. On this scale, 1 means unification 'has already gone too far' and 10 means it 'should be pushed further.' What number on this scale best describes your position?"

"And about where would you place the following parties on this scale?"

Party identification question to identify party supporters:

"Do you consider yourself to be close to any particular party? If so, which party do you feel close to?"

\section{References}

Adams, James, Lawrence Ezrow, and Zeynep Somer-Topcu. 2011. "Is Anybody Listening? Evidence That Voters Do Not Respond to European Parties' Policy Statements during Elections." American Journal of Political Science 55(2): 370-82.

Adams, James, Lawrence Ezrow, and Zeynep Somer-Topcu. 2014. "Do Voters Respond to Party Manifestos or to a Wider Informational Environment? An Analysis of MassElite Linkages on European Integration." American Journal of Political Science 58(4): 967-78.

Bakker, Ryan, Catherine de Vries, Erica Edwards, Liesbet Hooghe, Seth Jolly, Gary Marks, Jonathan Polk, Jan Rovny, Marco Steenbergen, and Milada Vachudova. 2015. "Measuring Party Positions in Europe: The Chapel Hill Expert Survey Trend File, 1999-2010." Party Politics 21(1): 143-52.

Bakker, Ryan, Seth Jolly, and Jonathan Polk. 2012. "Complexity in the European Party Space: Exploring Dimensionality with Experts." European Union Politics 13(2): 219-45.

Barnett, Adrian, Jolieke van derPouls, and Annette Dobson. 2005. "Regression to the Mean: What It Is and How to Deal with It." International Journal of Epidemiology 34(1): 215-20.

Benoit, Kenneth, Slava Mikhaylov, and Michael Laver. 2009. "Treating Words as Data with Error: Uncertainty in Text Statements of Policy Positions." American Journal of Political Science 53(2): 495-513.

Boudreau, Cheryl, and Scott A. MacKenzie. 2014. "Informing the Electorate? How Party Cues and Policy Information Affect Public Opinion about Initiatives." American Journal of Political Science 58(1): 48-62.

Budge, Ian. 1994. “A New Theory of Party Competition: Uncertainty, Ideology, and Policy Equilibria Temporally and Comparatively." British Journal of Political Science 24(2): 443-67.

Budge, Ian, Lawrence Ezrow, and Michael McDonald. 2010. "Ideology, Party Factionalism and Policy Change: An Integrated Dynamic Theory." British Journal of Political Science 40(4): 781-804.

Cahill, Christy, and James Adams. 2014. "Do Governing Coalition Partners Converge on Their Issue Positions? An Analysis of the Chapel Hill Expert Survey Data from 16 European Party Systems, 2006-2010.” Presented at the 
annual meeting of the Midwest Political Science Association, Chicago.

Calvo, Ernesto, and Timothy Hellwig. 2011. "Centripetal and Centrifugal Incentives under Different Electoral Systems." American Journal of Political Science 55(1): 27-41.

Dalton, Russell. 1985. "Political Parties and Political Representation.” Comparative Political Studies 17(3): 267-99.

Dalton, Russell, David Farrell, and Ian McAllister. 2011. Political Parties and Democratic Linkage: How Parties Organize Democracy. Oxford: Oxford University Press.

Dalton, Russell, and Ian McAllister. n.d. "Random Walk or Planned Excursion? Continuity and Change in the Left-Right Positions of Political Parties." Comparative Political Studies. Forthcoming.

Dancey, Logan, and Geoffrey Sheagley. 2013. "Heuristics Behaving Badly: Party Cues and Voter Knowledge." American Journal of Political Science 57(2): 312-25.

De Vreese, Claes H., Susan A. Banducci, Holli A. Semetko, and Hajo G. Boomgaarden. 2006. "The News Coverage of the 2004 European Parliamentary Election Campaign in 25 Countries." European Union Politics 7(4): 477-504.

De Vries, Catherine, and Sara Hobolt. 2012. "When Dimensions Collide: The Electoral Success of Issue Entrepreneurs." European Union Politics 13(2): 246-68.

Duch, Raymond, Wojtek Przepiorka, and Randolph T. Stevenson. 2013. "Responsibility Attributions for Collective Decision Makers." Unpublished manuscript.

Erikson, Robert, Michael MacKuen, and James Stimson. 2002. The Macro Polity. Cambridge: Cambridge University Press.

Evans, Geoffrey. 1998. "Euroscepticism and Conservative Electoral Support: How an Asset Became a Liability." British Journal of Political Science 28(4): 573-90.

Fernando-Vazquez, Pablo. 2014. “And Yet It Moves: The Effects of Election Manifestos on Party Policy Images." Comparative Political Studies 47(14): 1919-44.

Fortunato, David, and James Adams. n.d. "How Prime Ministers Influence Voters' Perceptions of Their Junior Partners." European Journal of Political Research. Forthcoming.

Fortunato, David, and Randy Stevenson. 2013. "Perceptions of Partisan Ideologies: The Effects of Coalition Participation." American Journal of Political Science 57(2): 459-77.

Franklin, Mark N., and Christopher Wlezien. 1997. "The Responsive Public: Issue Salience, Policy Change, and Preferences for European Unification." Journal of Theoretical Politics 9: 347-63.

Gabel, Matthew. 1998. "Public Opinion and European Integration: An Empirical Test of Five Theories." Journal of Politics 60: 333-54.

Ganghof, Steffen, and Thomas Brauninger. 2006. "Government Status and Legislative Behavior: Partisan Veto Players in Australia, Denmark, Finland, and Germany." Party Politics 12(4): 521-39.

Hooghe, Liesbet, Gary Marks, and Carole J. Wilson. 2002. "Does Left/Right Structure Party Positions on European Integration?" Comparative Political Studies 35(8): 965-89.
Lau, Richard, and David P. Redlawsk. 2001. “Advantages and Disadvantages of Cognitive Heuristics in Political Decision Making." American Journal of Political Science 45(4): 951-71.

Martin, Lanny W., and Randolph T. Stevenson. 2010. "The Conditional Impact of Incumbency on Government Formation." American Political Science Review 104(3): 503-18.

Muller, Wolfgang, and Kaare Strom. 2000. Coalition Governments in Western Europe. Oxford: Oxford University Press.

Powell, G. Bingham. 2000. Elections as Instruments of Democracy. New Haven, CT: Yale University Press.

Ray, Leonard. 2003a. "Reconsidering the Link between Incumbent Support and Pro-EU Opinion." European Union Politics 4(3): 259-80.

Ray, Leonard. 2003b. "When Parties Matter: The Conditional Influence of Party Positions on Voter Opinions about European Integration." Journal of Politics 65(4): 978-94.

Rogers, William H. 1993. "Regression Standard Errors in Clustered Samples." Stata Technical Bulletin 13: 19-23.

Soroka, Stuart, and Christopher Wlezien. 2010. Degrees of Democracy. New York: Cambridge University Press.

Steenbergen, Marco R., Erica E. Edwards, and Catherine E. De Vries. 2007. "Who Is Cueing Whom? Mass-Elite Linkages and the Future of European Integration." European Union Politics 8(1): 13-35.

Wlezien, Christopher, and Stuart Soroka. 2012. "Political Institutions and the Opinion-Policy Link." Western European Politics 35(6): 1407-32.

Woolridge, Jeffrey M. 2002. Econometric Analysis of Cross Section and Panel Data. Cambridge, MA: MIT Press.

\section{Supporting Information}

Additional Supporting Information may be found in the online version of this article at the publisher's website:

Table S1: Analyses of Citizens' Perceptions of Parties' Policy Shifts on European Integration, Omitting the Party's Lagged Perceived Position Variable.

Table S2: Analyses of Citizens' Perceptions of Parties' Policy Shifts on Europe for Different Levels of Unemployment, Inflation, and GDP Growth.

Table S3: Analyses of Citizens' Perceptions of Parties' Policy Shifts on European Integration, using Errors-in-Variables Analyses.

Table S4: Analyses of Party Supporters' Perceptions of Parties' Policy Shifts, compared to Perceptions Computed over all Respondents $(\mathrm{N}=56)$.

Table S5: Analyses of Partisan Sorting on European Integration, Measuring Parties' Positions on European Integration based on Independent Voters' Perceptions. 